\title{
3.8 INNOVATION SUPPORT FROM R\&D INSTITUTIONS IN SMALL AND MEDIUM-SIZED ENTERPRISES IN THE BALTIC SEA REGION
}

\begin{abstract}
Summary: The paper presents the importance of the cooperation between research and development institutions and the small and medium-sized enterprises (SMEs) in the process of creation the innovation. This paper is based on the research carried out in March/April 2011. 542 enterprises from 9 Baltic Sea Region (BSR) countries took part in the study: Latvia, Sweden, Estonia, Finland, Norway, Lithuania, Germany, Russia, and Poland. The aim of the study was to analyze the actual innovation support from R\&D institution for SMEs from the Baltic Sea Region. Research activities of this study include: the evaluation of barriers in innovation implementation in Baltic Sea Region enterprises, the study of SMEs cooperation with scientific subjects, R\&D sphere; and the identification of the needs of enterprises to do with the increase of their innovation capacities such as: demand for training, consulting, cooperation with universities and $R \& D$ sphere, or cooperation in a cluster.

Partnership with R\&D institutions is vital especially for SME's, which have fewer employees and a smaller financial potential. Unlike major companies, SMEs do not have own R\&D departments, but need external services tailored to their needs. During last years SMEs in Baltic Sea Region have been massively improving the efficiency through cost reduction, business process re-engineering etc. SMEs need innovations and qualifications which requires an intensive cooperation with science. By an improved this cooperation, transfer of technologies and knowledge can be been fortified lastingly and used development potentials.
\end{abstract}

Keywords: SMEs, innovation, R\&D institutions

\section{INTRODUCTION}

The Baltic Sea Region covers the area consisting of eleven countries: Denmark, Estonia, Finland, Germany (with the following lands: Berlin, Brandenburg, Bremen, Hamburg, Maklenburg - West Pomerania, Schleswig-Holstein and Low Saxony), Latvia, Lithuania, Poland, Sweden, Belarus, Norway and Russia (Sankt Petersburg and Leningrad Region, Karelia Republic, Kaliningrad, Murmansk, Novogrod and Pskov regions). With the increasing integration of world, economy becomes increasingly important competitive of small and medium-sized businesses globally. One way to counter the increased competition is creating innovation and translating it into useful applications for the market (Organisation for Economic Co-operation and Development (OECD), 2010).

The most important priority of the Baltic Sea Region strategy focuses on generating, supporting and distribution of innovation in the region. It supports activities designed to help innovation development of natural and technical sciences as well as chosen non-technical sciences such as business services and design (Portal Funduszy Europejskich, http://www.ewt.gov.pl, April 2012). Activities in this priority should analyze and increase the efficiency of the sources of innovation and their relationships with small and medium-sized enterprises (SMEs). They should also facilitate transnational technology and scientific transfer as well as increase the possibilities of generating knowledge and its absorption by different social groups. 


\section{THE AIM AND SCOPE OF THE STUDY}

Enterprises from 9 Baltic Sea Region countries took part in the study. As a result of the study 542 filled-in questionnaires were gathered, among which 2 came from Latvia, 3 from Sweden, 11 from Estonia, 4 from Finland, 25 from Norway, 24 from Lithuania, 16 from Germany, 11 from Russia and 446 from Poland. The survey was conducted in March/April 2011. The questionnaires completed by Polish entrepreneurs amounted to $82,3 \%$ of the total number of all gathered questionnaires. For this reason, the analysis contained in this report concerning the need of enterprises for innovation support is based mainly on the answers given by the Polish entrepreneurs. These results were compared, where possible, with the results obtained from enterprises coming from chosen Baltic Sea Region countries (Norway, Lithuania, Germany, and Russia) where the largest number of completed questionnaires was gathered during the study. However, the sample of enterprises chosen for the study was not representative. Moreover, the research group did not define a desired structure of such a sample. The conducted research was then of a tentative type only and its conclusions should be interpreted in this light.

The aim of the study was to analyze the actual innovation support from R\&D institution for SMEs from the Baltic Sea Region. Research activities of this study include: the evaluation of barriers in innovation implementation in Baltic Sea Region enterprises, the study of SMEs cooperation with scientific subjects, R\&D sphere; and the identification of the needs of enterprises to do with the increase of their innovation capacities such as: demand for training, consulting, cooperation with universities and $R \& D$ sphere, or cooperation in a cluster.

The results of the conducted study can help formulate recommendations designed to increase innovation and competitiveness of SMEs from Baltic Sea Region in the future. Today, it seems, it is well understood that effective and dynamic innovation processes in economy are interactive and they require cooperation of many business subjects and institutions from business environment.

\subsection{DESCRIPTION OF THE ANALYZED ENTERPRISES}

446 Polish enterprises took part in the study. Service enterprises constitute the biggest share (44\%) in the analyzed group. They are followed by trade companies $(36 \%) .8$ out of each 10 analyzed Polish enterprises are from trade and service sectors. Predominantly they come from the following sectors: food, clothing, shoe and automobile industries, and cosmetic services.

The structure of the analyzed enterprises according to the sectors they come from is quite similar in the remaining Baltic Sea region countries (see table 1). In all the analyzed countries, enterprises from service and trade sectors constituted $3 / 4$ of the group.

Table 1: The structure of the analyzed enterprises from Norway, Lithuania, Germany and Russia, according to the sector (in \%)

\begin{tabular}{|l|c|c|c|c|}
\hline \multicolumn{1}{|c|}{ Sector } & Norway & Lithuania & Germany & Russia \\
\hline \hline services & 52 & 42 & 38 & 66 \\
\hline trade & 28 & 35 & 33 & 21 \\
\hline production & 14 & 16 & 19 & 7 \\
\hline mixed & 6 & 6 & 10 & 7 \\
\hline
\end{tabular}

Source: own study

Data: $\mathrm{N}$ for Norway $=25, \mathrm{~N}$ for Lithuania $=24, \mathrm{~N}$ for Germany $=16, \mathrm{~N}$ for Russia $=11$ 
The sector structure of the analyzed Polish enterprises is consistent with general sectoral characteristics of SMEs. SMEs in Poland are to be found in all sectors of economy, but they dominate in service sector. The market share of microenterprises is especially big in the following sectors: real estate (98\%), transportation (98\%), trade $(97 \%)$, construction $(96 \%)$, hotel and gastronomy (95\%) and fishing (95\%).

Microenterprises employing from 1 to 9 people yearly account for $(67 \%)$ of all enterprises in the analyzed sample of Polish enterprises. Small enterprises, employing from 10 to 49 people amount to $20 \%$ of this number and medium-sized enterprises constitute only $7 \%$ of all the analyzed enterprises. Predominance of microenterprises over small and medium-sized enterprises in the analyzed sample of the SMEs is evident, yet it is a typical phenomenon for Polish economy, for according to GUS and PARP, microenterprises (employing maximum 9 people) amount to about $95 \%$ of all private enterprises in Poland (3,6 million). Small and medium-sized enterprises account for the remaining $5 \%$. Mean employment in a Polish enterprise amounts to 5 employees [Główny Urząd Statystyczny (GUS), 2011]. Polish SMEs are dominated by microenterprises more than other SMEs from the Baltic Sea region countries.

Microenterprises are also dominant in the remaining Baltic Sea region countries of the analyzed group. In Norway and Germany they constitute $1 / 2$ of the analyzed enterprises, and more than $1 / 3$ in Lithuania and Russia. In Norway and Germany 8 out of 10 analyzed enterprises employed up to 49 people, whereas in Lithuania and Russia 7 out of 10 enterprises belong to micro and small enterprises. In these countries, a larger representation of mediumsized enterprises is to be found in the analyzed group, compared to the group of the Polish enterprises.

Table 2: The structure of the analyzed enterprises from Norway, Lithuania, Germany and Russia, according to the employment (in \%)

\begin{tabular}{|l|c|c|c|c|}
\hline Employment & Norway & Lithuania & Germany & Russia \\
\hline \hline 1 to 9 & 52 & 33,3 & 50 & 36,4 \\
\hline $10-49$ & 32 & 33,3 & 31,3 & 27,3 \\
\hline $50-249$ & 16 & 29,2 & 18,8 & 27,3 \\
\hline over 250 & 0 & 4,2 & 0 & 9,1 \\
\hline
\end{tabular}

Source: own study

Data: $\mathrm{N}$ for Norway $=25, \mathrm{~N}$ for Lithuania $=24, \mathrm{~N}$ for Germany $=16, \mathrm{~N}$ for Russia $=11$

Since the analyzed group in all countries in this study is composed mainly of micro and small enterprises, their age is an important factor. Start-ups and new enterprises, whose main problem is the survival on the market look at the issue of support and development of innovation differently compared to a mature, stable enterprise whose task is to gain its competitive edge on the market. In the analyzed group of the Polish enterprises, 7 out of 10 are stable companies, which have been on the market for more than 5 years. A similar ratio is to be found for the analyzed group of the Lithuanian, German and Russian enterprises. The group of the Norwegian enterprises stands out in this respect since $96 \%$ of them have been on the market for more than 10 years. To sum up, the analyzed group of the enterprises from all the countries is composed mainly of mature and stable companies.

\section{BARRIERS IN INNOVATIONS IMPLEMENTATION}

An important issue for the assessment of innovation potential of the Baltic Sea Region SMEs is specifying factors, which influence the increase of innovation activity. Identification and abolishment of barriers, which restrict the implementation of innovation into the market, 
seems important. When asked about barriers they encounter when implementing innovations, the enterprises have mentioned problems that can be found in the literature devoted to innovations in SMEs. For more than a half of the Polish SMEs insufficient funds are the major difficulty in innovation activities.

Figure 1: Barriers in implementation of innovation according to Polish SMEs (in \%)

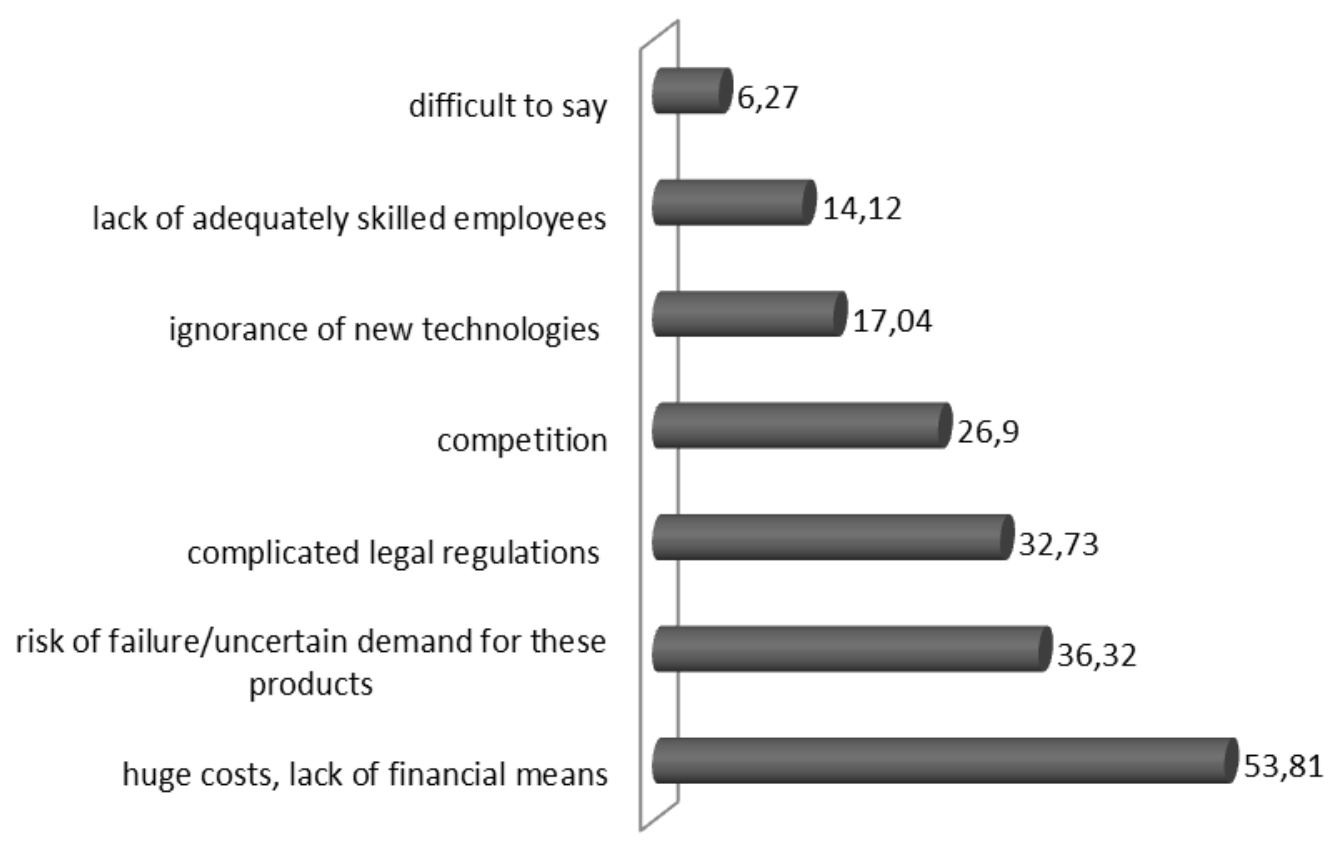

Source: own study, data: $\mathrm{N}$ for Poland=446, note: enterprises could choose up to 8 answers

According to GUS research, the main source of financing innovations in SMEs is their own financial means $(74,75 \%)$, and bank loans amount to $22 \%$ only in this respect. For $1 / 3$ of the Polish SMEs risk of investment failure in innovations, and uncertain demand for new products constitute a major problem. A smaller fraction of the analyzed Polish SMEs $(32 \%$ enterprises) have pointed at too complicated legal regulations as a major obstacle in their innovation activity.

Similarly, the analyzed SMEs in Norway, Germany, Lithuania and Russia claimed insufficient financial means was a major barrier for them. This was a problem for $64 \%$ of the Norwegian companies, $66,7 \%$ of the Lithuanian companies, $68,7 \%$ of the German companies and $46,7 \%$ SMEs from Russia. Complicated procedures in innovations implementation, lack of qualified employees and existing market competition have also been an issue.

The conducted research has allowed to bring to light some specific barriers in innovations implementation in each of the analyzed countries. These barriers are important for one specific country and are not for others; i.e. for the Polish and Lithuanian SMEs it is uncertainty of investments in innovations, for the Norwegian enterprises competition and for the German SMEs lack of properly qualified staff.

\section{SMEs CONTACTS WITH SCIENTIFIC, R\&D, AND OTHER INSTITUTIONS}

In modern highly competitive economy the ability and intensity of cooperation on innovations has taken on a particular importance. This cooperation is vital especially for SMEs, which have fewer employees and a smaller financial potential. This analysis of SMEs, as far as innovations are concerned, indicates that a role of a leading partner is played by local authorities, chambers of commerce, chambers of crafts and entrepreneurs' associations. 
As much as $12,6 \%$ of the Polish SMEs have cooperated with local authorities. A cooperation with other enterprises is a common denominator for the analyzed SMEs. $26,2 \%$ of the SMEs have declared such a cooperation. It is worth mentioning that cooperation between enterprises is especially important, since according to numerous studies, a number of enterprises, which have permanent business contacts with other companies, is strongly correlated with their innovation activity. Contacts with $R \& D$ institutions are a particularly important type of cooperation from the point of view of innovation potential increase. It is due to the fact that SMEs seldom engage in R\&D on account of high costs of such an ventures, lack of qualified staff, and lack of necessary equipment. Only 16,37\% of the Polish SMEs could boast of a current cooperation with scientific and R\&D institutions. It can be inferred than that the majority of implemented innovative solutions in the surveyed SMEs is a result of their own effort, without resorting to cooperation with scientific centres and R\&D institutions.

Table 3: The Baltic Sea Region SMEs cooperation on innovations until present (in \%)

\begin{tabular}{|l|c|c|c|c|c|}
\hline & Poland & Norway & Lithuania & Germany & Russia \\
\hline \hline Local authorities & 12,6 & 44 & 37,5 & 56,3 & 36,4 \\
\hline Local administration & 9,8 & 24 & 25,8 & 25 & 18,6 \\
\hline Consulting companies & 9,8 & 4 & 0 & 25 & 27,3 \\
\hline Financial institutions & 9,6 & 4 & 58,3 & 25 & 0 \\
\hline Business support institutions & 7,8 & 4 & 12,5 & 12,5 & 36,4 \\
\hline Universities & 5,8 & 8 & 33,3 & 31,3 & 27,3 \\
\hline R\&D institutions & 2,2 & 24 & 25 & 12,5 & 18,2 \\
\hline Other entrepreneurs & 26,2 & 16 & 16,6 & 37,5 & 9,1 \\
\hline
\end{tabular}

Source: own study

Data: $\mathrm{N}$ for Norway $=25, \mathrm{~N}$ for Lithuania $=24, \mathrm{~N}$ for Germany $=16, \mathrm{~N}$ for Russia $=11$

As much as $56,3 \%$ of the German, $44 \%$ of the Norwegian, $37,5 \%$ of the Lithuanian and $36,4 \%$ of the Russian SMEs have cooperated with local authorities. As for the Polish SMEs, only $12,6 \%$ have done it. A cooperation with other enterprises is a common denominator for the Polish and German SMEs. 26,2\% of the Polish and 37,5\% of the German SMEs have declared such a cooperation. It is worth mentioning that cooperation between enterprises is especially important, since according to numerous studies, a number of enterprises, which have permanent business contacts with other companies, is strongly correlated with their innovation activity. In the analyzed SMEs, the SMEs from Lithuania, Germany and Russia stand out in this respect. In these countries, a substantial fraction of SMEs have cooperated on innovations with different institutions. In Lithuania 58,3 \% of the SMEs have cooperated with financial institutions, and $36,4 \%$ of the SMEs in Russia have cooperated with business support institutions.

The conducted research shows that universities are the most frequently chosen R\&D partner by the Baltic Sea Region SMEs. More than a half of the Lithuanian SMEs, $44 \%$ of the German SMEs and more than a third of the Russian SMEs have permanently cooperated with universities when this research was done. Poland is no exception in this respect even though only $5,6 \%$ of the analyzed Polish SMEs have cooperated with universities. Generally, Polish SMEs cooperate much less intensely with R\&D institutions in comparison with SMEs from the remaining countries. Apart from cooperation with universities, a specific type of specialization of the Baltic Sea Region SMEs and R\&D institutions looms large. As much as $40 \%$ of the Norwegian SMEs have cooperated with a cluster, 33,3\% of the Lithuanian and $25 \%$ of the German SMEs have cooperated with scientific and R\&D institutions, and 27,3\% of the Russian SMEs have cooperated with technology transfer centres when this research was done. 


\subsection{TYPES OF CONDUCTED R\&D ACTIVITIES}

As it has already been mentioned SMEs rarely engage in R\&D activities. In Poland SMEs which occasionally conduct R\&D research account for 3,8\% of all SMEs, and only $1,85 \%$ of the Polish SMEs can boast of a permanent activity of this type (Żołnierski, 2008).

Figure 2: A number of the analyzed SMEs, which are not engaged in R\&D (in \%)

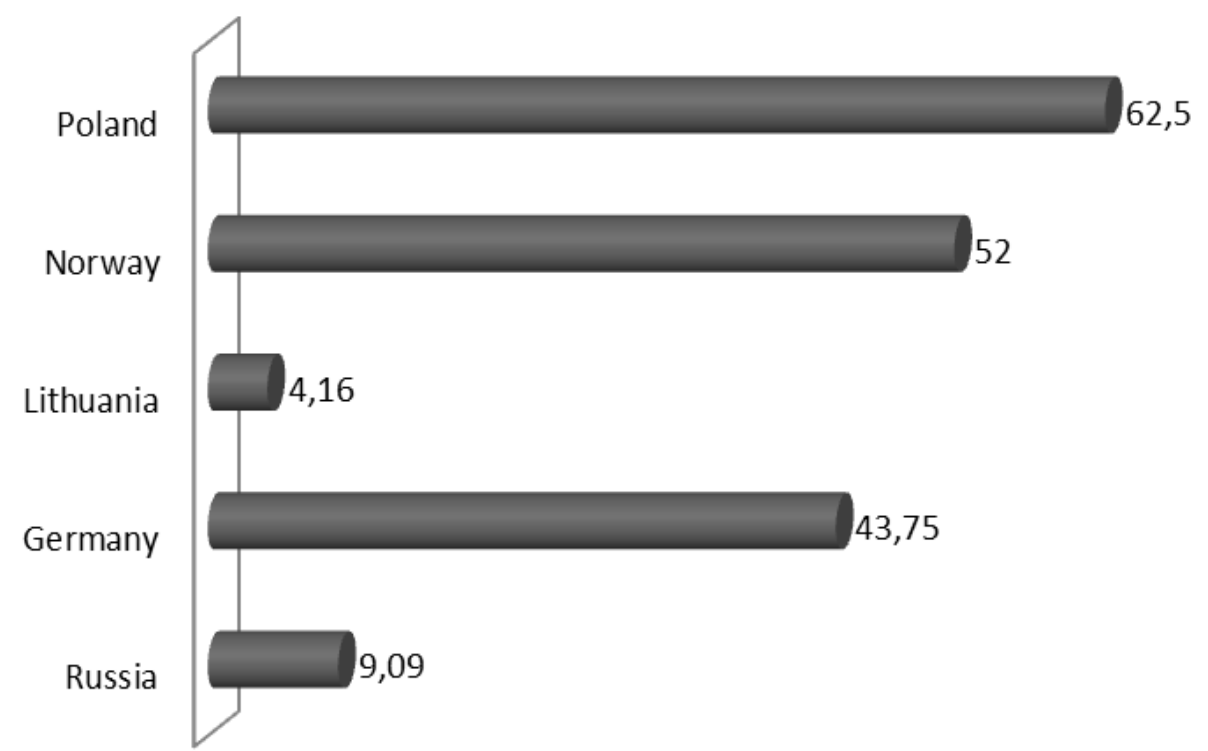

Source: own study

Data: $\mathrm{N}$ for Norway $=25, \mathrm{~N}$ for Lithuania $=24, \mathrm{~N}$ for Germany $=16, \mathrm{~N}$ for Russia $=11$

In the analyzed Polish SMEs, a fraction of companies which have not been engaged in R\&D is very high and amounts to $62,5 \%$ of all analyzed enterprises. Similarly, a half of the analyzed Norwegian and German enterprises have not been engaged in any R\&D activity when this study was conducted. The only exception to this rule are the Russian and Lithuanian SMEs where 9 out of 10 enterprises have been engaged in R\&D activities.

A predominant kind of R\&D conducted by the Baltic Sea Region SMEs concerns enhancements in production and services. This kind of activity has been conducted by $1 / 4$ of the Polish SMEs, over 1/3 of the Lithuanian and German SMEs, $44 \%$ of the Norwegian SMEs, and more than a half of the Russian SMEs.

Cooperation with scientific co-operation is relatively easy, requiring long-term planning tasks, which to be made by the unit. However, research shows that in the presence of missing the initiative private institutions research laboratories, with which the firms have pursued the implementation of innovative tasks, which may improve the competitiveness and quality of services offered by universities, which - as they consider respondents - significantly simplify collaboration with universities and the struggle against bureaucracy.

\subsection{BARRIERS IN COOPERATION BETWEEN SMES AND SCIENTIFIC INSTITUTIONS}

On account of a relatively poor cooperation of the Baltic Sea Region SMEs with R\&D institutions, the author of this paper have undertaken a task of identifying problems in SMEs and R\&D institutions cooperation. A majority of the analyzed SMEs have come across a proposal of cooperation on behalf of a scientific institution (89\% of the Polish SMEs, about $72 \%$ of the Norwegian SMEs, and about $66 \%$ of the German and Russian SMEs). Lithuania stands out as an exception with only $50 \%$ of the companies declaring such contacts. It turns 
out, however, that 9 out of 10 of all the analyzed firms can see barriers in cooperation with scientific institutions. Basing on the completed questionnaires, it can be inferred that the main barrier preventing such a cooperation is a limited financial potential of the SMEs.

Table 4: Barriers preventing cooperation between SMEs and R\&D institutions (in \%)

\begin{tabular}{|l|c|c|c|c|c|}
\hline & Poland & Norway & Lithuania & Germany & Russia \\
\hline substantial costs, financial barriers & 41 & 76 & 50 & 37,5 & 54,5 \\
\hline difficulties with starting a cooperation & 28,5 & 32 & 33,3 & 31,2 & 36,3 \\
\hline $\begin{array}{l}\text { lack of interest of R\&D institutions to start } \\
\text { a cooperation }\end{array}$ & 19,7 & 28 & 41,7 & 18,7 & 18,8 \\
\hline $\begin{array}{l}\text { R\&D representatives do not understand the } \\
\text { issue }\end{array}$ & 18,4 & 64 & 45,8 & 25 & 27,3 \\
\hline legal barriers & 17,9 & 4 & 8,3 & $\mathrm{x}$ & $\mathrm{x}$ \\
\hline no barriers & 11,4 & 8 & $\mathrm{x}$ & 6,3 & 18,2 \\
\hline $\begin{array}{l}\text { communication problems with R\&D } \\
\text { representatives }\end{array}$ & 10,3 & 36 & 29,16 & 12,5 & $\mathrm{x}$ \\
\hline
\end{tabular}

Source: own study

Data: $\mathrm{N}$ for Norway $=25, \mathrm{~N}$ for Lithuania $=24, \mathrm{~N}$ for Germany $=16, \mathrm{~N}$ for Russia $=11$

This problem is due to limited financial resources of the enterprises for joint research as well as a difficult access to external financing of $R \& D$ projects carried out together with $R \& D$ institutions. It should be noticed, however, that SMEs believe that a low intensity of cooperation with $R \& D$ institutions is caused by $R \& D$ institutions themselves. About 1/3 of the analyzed companies have encountered problems with starting a cooperation with scientific institutions. On average 1 in 5 of the analyzed SMEs has shown a lack of interest on behalf of the scientific institution to initiate a cooperation with enterprises on R\&D projects. Moreover, a substantial fraction of the analyzed companies (64\% from Norway, $46 \%$ from Lithuania, $25 \%$ from Germany and Russia, and 4\% from Poland) have declared that representatives from $\mathrm{R} \& \mathrm{D}$ institutions ignore economic matters, which prevents or limits a possible cooperation.

\section{DEMAND FOR R\&D IN SMES}

One of the fundamental objectives of this report is to estimate the demand for innovation of the Baltic Sea Region SMEs. To do this, a potential demand for R\&D in SMEs has been analyzed in the first place. It turns out that $2 / 3$ of the Lithuanian and Russian SMEs over $1 / 2$ of the Norwegian SMEs and 43,7\% of the analyzed German enterprises need R\&D. Polish SMEs do not do well in this respect, because only 1 from the 3 Polish enterprises declares a demand for R\&D in their company.

Moreover, 1/4 of the German, Lithuanian, Norwegian and Polish enterprises on average, do not have any opinion about possible demand for R\&D in the future. It probably indicates that the analyzed SMEs do not quite understand what underlies innovative solutions creation in company, because they do not understand the importance of R\&D. It is obvious that understanding and verbalizing a demand for $R \& D$ is only a first step in planning innovation processes in the company. A company can understand the necessity of R\&D to increase the level of innovation, yet because of some restricting conditions, it will not intend to engage in any R\&D activity. This is why the next step in this research was to analyze the Baltic Sea Region SMEs' intentions to engage in and order R\&D or to buy their results in the future. 
Figure 3: SMEs intentions to engage in or order R\&D or to buy their results (in \%)

ano $\square$ yes $\square$ l have no opinion

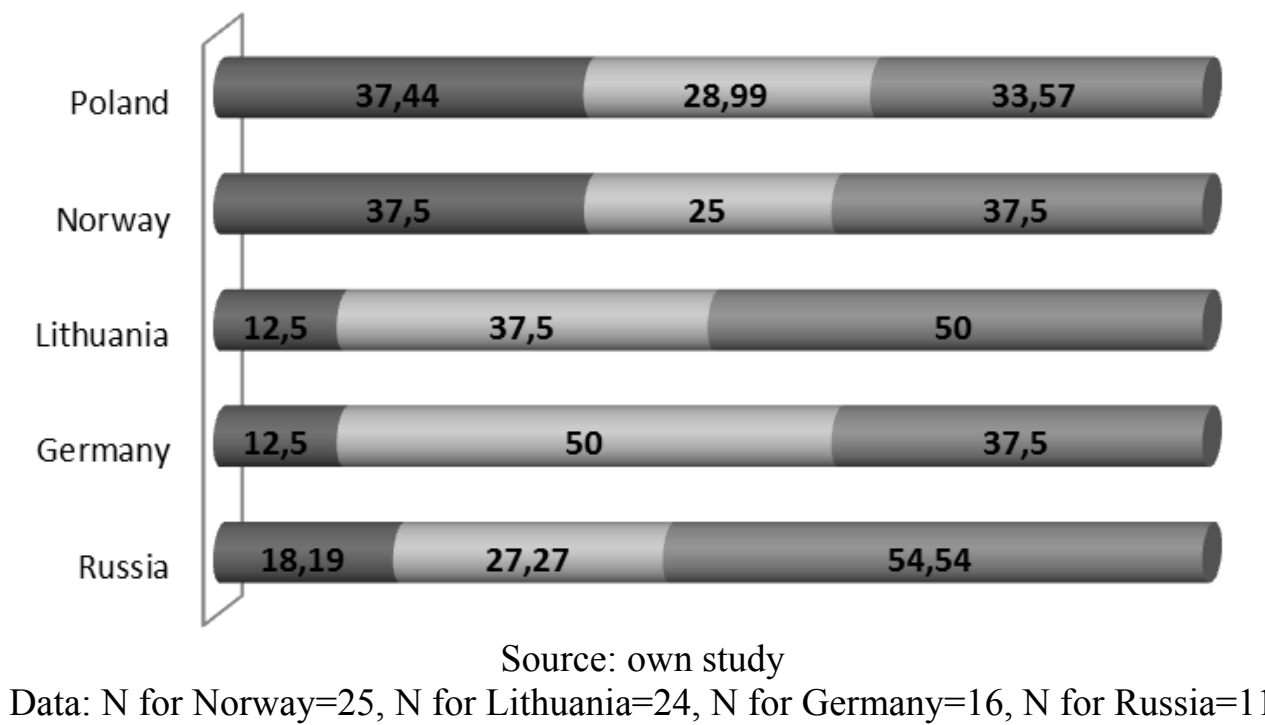

Therefore, the next step in this research was to analyze the SMEs' intentions to engage in and order $\mathrm{R} \& \mathrm{D}$ or to buy their results in the future. It turns out that a number of the Lithuanian, Norwegian, and Russian enterprises declaring readiness to engage in, order or buy R\&D is twice smaller than a number of the SMEs in these countries, which declare a demand for R\&D. Only in Poland and Germany a demand for and a potential supply of R\&D go hand in hand.

A substantial number of the analyzed companies, which do not have any specific plans to engage in, order or buy R\&D indicates that SMEs are hesitant about incorporation of potential R\&D projects. As $1 / 2$ of the Lithuanian and Russian SMEs and over 1/3 of the SMEs from Germany, Norway and Poland do not have any opinion about running, ordering or buying $R \& D$ projects. It is probably due to barriers in $R \& D$ implementation in SMEs mentioned before.

\subsection{SMES DEMAND FOR INNOVATION SUPPORT FROM UNIVERSITIES}

In this study, an attempt has been made to identify the scope and type of innovation support SMEs require from scientific institutions. A demand for a specific sort of support from universities is much smaller than the analyzed demand for R\&D. In the majority of the analyzed countries, an interest in a specific kind of support has been declared on average by $1 / 3$ of the total number of the SMEs. The entrepreneurs have been mostly interested in periodical trainings and workshops for companies preparing and realizing innovative projects. A demand for this kind of support has been declared by more than a half of the Norwegian and Lithuanian enterprises, about $1 / 3$ of the Polish and Russian companies and 1/5 of the German SMEs. 1 in 3 SMEs from Poland, Lithuania and Germany, $42 \%$ of the Norwegian SMEs and close to $3 / 4$ of the Russian SMEs have shown interest in information meeting concerning a specific types and kinds of innovations.

Moreover, entrepreneurs have shown a potential interest in individual consulting services directly in their companies. This form of support has been of interest to $2 / 3$ of the Lithuanian SMEs, over $1 / 3$ of the Norwegian enterprises and to every fifth company from Poland, Germany and Russia. 
The analysis of potential benefits, which SMEs can expect from the cooperation with scientific institutions, can lead to interesting conclusions. Only few analyzed SMEs can see potential benefits, which can result from such a cooperation.

Table 5: SMEs demand for innovation support from universities (in \%)

\begin{tabular}{|l|c|c|c|c|c|}
\hline & Poland & Norway & Lithuania & Germany & Russia \\
\hline $\begin{array}{l}\text { periodical trainings and workshops for } \\
\text { persons preparing and realizing } \\
\text { innovative projects }\end{array}$ & 35,5 & 58,3 & 50 & 20 & 36,6 \\
\hline $\begin{array}{l}\text { information meetings on types and kinds } \\
\text { of innovations }\end{array}$ & 30,7 & 41,6 & 37,5 & 33,3 & 72,3 \\
\hline $\begin{array}{l}\text { allowing access to practical training and } \\
\text { didactical materials }\end{array}$ & 22,6 & 16,7 & 16,7 & 20 & 36,4 \\
\hline $\begin{array}{l}\text { individual consulting directly in the } \\
\text { company }\end{array}$ & 22,6 & 37,5 & 62,5 & 26,7 & 18,2 \\
\hline individual consulting via e-mail & 11,5 & 16,7 & 16,7 & $\mathrm{x}$ & $\mathrm{x}$ \\
\hline individual consulting by phone & 7,3 & 20,8 & 16,7 & $\mathrm{x}$ & $\mathrm{x}$ \\
\hline
\end{tabular}

Source: own study

Data: $\mathrm{N}$ for Norway $=25, \mathrm{~N}$ for Lithuania $=24, \mathrm{~N}$ for Germany $=16, \mathrm{~N}$ for Russia $=11$

The smallest number of SMEs which have a positive opinion on a cooperation with universities is to be found in Poland (22\% on average), and the biggest in Lithuania ( $48 \%$ on average). Generally according to the opinion expressed by the majority of SMEs, benefits from the analyzed cooperation are different in each country. The only common benefit coming from the cooperation with universities that a substantial number of SMEs from all the countries have agreed upon is "launching new products and services". This is the most important benefit for the Polish, German and Russian SMEs. It is also highly valued in Lithuania (62,5\%) and in Norway (44\%).

Moreover, the Polish SMEs look at a cooperation with universities as a means of boosting sales, getting new customers and increasing their market share. The Norwegian SMEs expect this cooperation to result in enhancing the quality of their products and reducing costs. The Lithuanian SMEs emphasize cost reduction and new technology implementation as a potential benefit from such a cooperation, whereas the German SMEs expect to improve the quality of their products and services and to get access to the latest know-how. Finally, the Russian SMEs expect to improve the quality of their products and services and to enhance organization in the company.

Apart from the demand for R\&D, the author of this article has analyzed the Baltic Sea Region SMEs in terms of their demand for training and consulting services from scientific circles. Moreover, the author has tried to specify which barriers impede a possible cooperation between entrepreneurs and scientists. It turns out that a substantial number of the SMEs are interested in this kind of support. As many as 9 out of 10 of the analyzed Polish and Russian SMEs $3 / 4$ of the Lithuanian companies and over $2 / 3$ of the Norwegian and German SMEs have declared readiness to participate in trainings and a demand for consulting services on cooperation from scientific circles.

Moreover, the enterprises taking part in this study, have been asked to specify what they would like to cooperate with universities on? It turns out, that in all the analyzed SMEs have pointed at 3 common subjects that are of interest to them in view of a possible cooperation: services, products and new technologies. Almost 2/3 of the Lithuanian SMEs, about $48 \%$ of the Russian SMEs, $40 \%$ of the Polish and Norwegian SMEs and 1 in 3 German SMEs have declared a need for such a cooperation. Only 1 in 5 from Poland and Russia and 1 in 4 SMEs 
from Lithuania, Norway and Germany has been interested in cooperation concerning the improvement of internal process in the company and staff development.

Table 6: Expected benefits SMEs can get resulted by their R\&D cooperation with universities (in \%)

\begin{tabular}{|l|c|c|c|c|c|}
\hline & Poland & Norway & Lithuania & Germany & Russia \\
\hline launching new products/services & 38,1 & 44 & 62,5 & 50 & 81,8 \\
\hline sales increase & 33,8 & 52 & 58,3 & 25 & 27,3 \\
\hline $\begin{array}{l}\text { improvement of cooperation with } \\
\text { suppliers and customers }\end{array}$ & 30,7 & 48 & 25 & 31,2 & 27,3 \\
\hline $\begin{array}{l}\text { gaining new customers/increasing } \\
\text { market share }\end{array}$ & 30,2 & 40 & 45,8 & 25 & 45,4 \\
\hline increase of company's prestige & 27,3 & 52 & 45,8 & 37,5 & 36,3 \\
\hline costs lowering & 27,1 & 56 & 75 & 31,2 & 27,3 \\
\hline enhancing products/services quality & 21,3 & 60 & 54,1 & 50 & 63,6 \\
\hline $\begin{array}{l}\text { optimalization of organization } \\
\text { operations }\end{array}$ & 20,1 & 20 & 37,5 & 43,7 & 45,4 \\
\hline access to latest know-how & 17,9 & 44 & 25 & 50 & 27,3 \\
\hline improvement of competitive position & 17,7 & 28 & 58,3 & 32,5 & 45,4 \\
\hline increase of company's profitability & 17,3 & 52 & 45,8 & 25 & 27,3 \\
\hline $\begin{array}{l}\text { possibilities of new innovations } \\
\text { implementations }\end{array}$ & 16,1 & 16 & 62,5 & 31,2 & 27,3 \\
\hline possibilities of HR development & 9,6 & 16 & 33,3 & 25 & 9,09 \\
\hline increase of ecological activity & 7,8 & 24 & 41,6 & 18,7 & $\mathrm{x}$ \\
\hline
\end{tabular}

Source: own study

Data: $\mathrm{N}$ for Norway $=25, \mathrm{~N}$ for Lithuania $=24, \mathrm{~N}$ for Germany $=16, \mathrm{~N}$ for Russia $=11$

SMEs are driven by cash flow and getting products quickly to market, which requires rapid decision-making and actions. Universities, on the other hand, are driven by other imperatives and they must follow institutional procedures, meaning that in commercial dealings with SMEs the parties are likely to frustrate each other. They sometimes feel obliged to extract the maximum financial benefit, while SMEs are generally unwilling and/or unable to pay large amounts for formal knowledge.

Universities tend to be more process driven and formal in their dealings, emphasizing intellectual property and contracts. It seems that SMEs prefer relationships with individuals versus institutions, seeking to bypass formal structures at universities to deal directly with researchers who they respect and trust.

SMEs also appear to adopt a more market-oriented view, valuing adaptation and incremental innovation of existing products and ideas with proven market potential rather than big breakthroughs which they are generally not resourced to pursue. Universities, on the other hand, appear more interested in 'blue skies' research and ideas-driven radical innovations which may, or may not, have commercial applications.

\section{SMEs DEMAND FOR CLUSTER PARTICIPATION}

Cluster is defined as a geographical concentration of reciprocally interrelated companies, specialized suppliers, service suppliers, companies operating in related sectors and relevant institutions (i.e. universities, normalization organizations and sectoral associations) which cooperate and compete with one another in particular fields'. The research on clusters carried out so far has shown that there are substantial economic benefits resulting from cluster activities, both for the economy and companies operating in the cluster. From a micro-scale 
point of view, companies operating in a cluster can inexpensively get information about the environment, properly assess their capacities, get a better access to suppliers and companies providing specialized services and specialized work market. More importantly, however, the existence of clusters fosters intellectual capital growth in companies, which are gathered in them. Consequently, this growth spurs technological transfer and facilitates innovation implementation in companies in a cluster. Therefore, companies operating in clusters have a higher level of innovation than enterprises which do not belong to any cluster organization.

In the light of this, the authors of this report have decided to analyze to which extent the Baltic Sea Region SMEs are engaged in cluster cooperation concerning innovation. It turns out that the majority of the analyzed companies could not boast of any cluster membership. This is true for $96,3 \%$ of the Polish companies, about $1 / 2$ of the Russian and Norwegian SMEs, $1 / 3$ of the Lithuanian SMEs and $14,8 \%$ of the German SMEs. The above results show a relatively low level of SMEs involvement in this kind of cooperation.

Figure 4: SMEs membership in innovation clusters (in \%)

- yes no

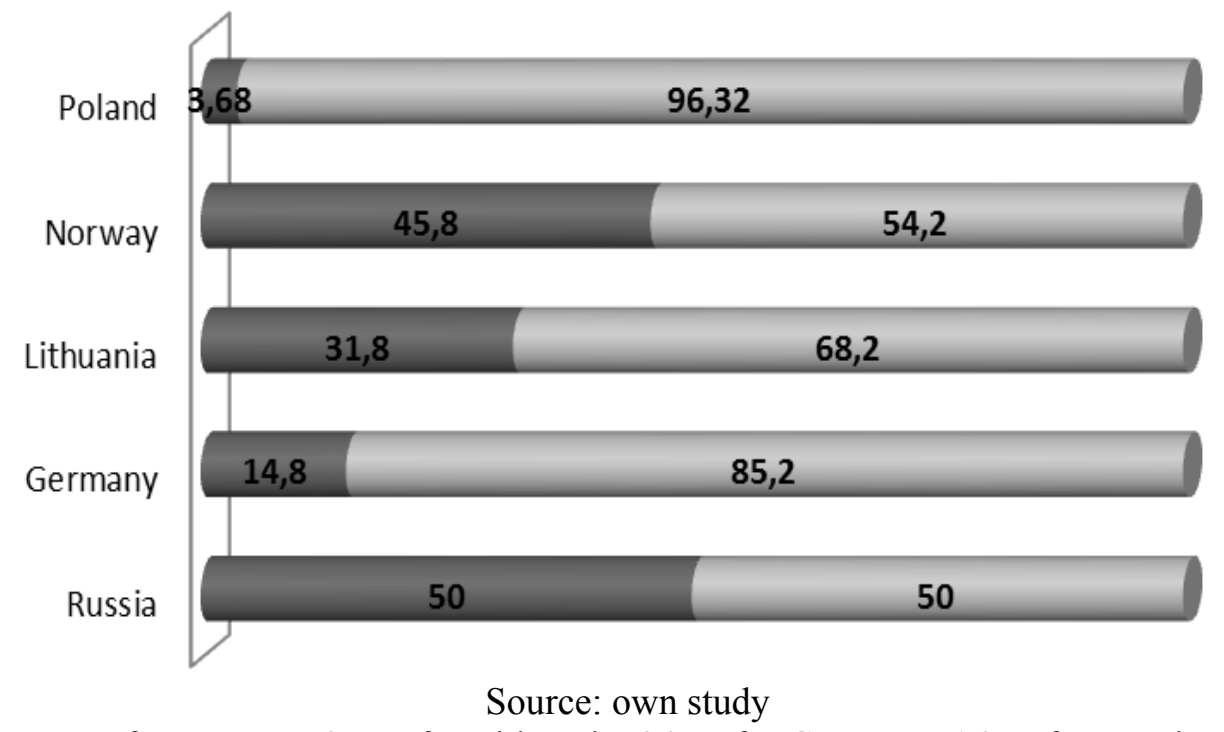

Data: $\mathrm{N}$ for Norway $=25, \mathrm{~N}$ for Lithuania $=24, \mathrm{~N}$ for Germany $=16, \mathrm{~N}$ for Russia $=11$

As competitiveness increases in all sectors of the economy in the Baltic Sea Region, different forms of associations and cooperation loom large as a means of SMEs growth and survival. Cluster organizations have become vital in this respect. For this reason, SMEs have been analyzed in view of a potential cluster cooperation in the future. The results of this study are not optimistic. As much as $81 \%$ of the Polish, $73 \%$ of the German and $58,4 \%$ of the Norwegian SMEs have declared no intention to cooperate in a cluster. The Lithuanian and Russian SMEs are an exception in this respect, since 70,8\% of the Lithuanian companies and $88,8 \%$ of the Russian SMEs have declared interest in cluster ventures as a means of improving their innovation and competitiveness.

Generally, these results indicate that it is necessary to undertake intense activity to increase SMEs' understanding of benefits flowing from mutual cooperation in a cluster. 
Figure 5: SMEs' willingness to cooperate in cluster ventures (in \%)

no $\square$ yes

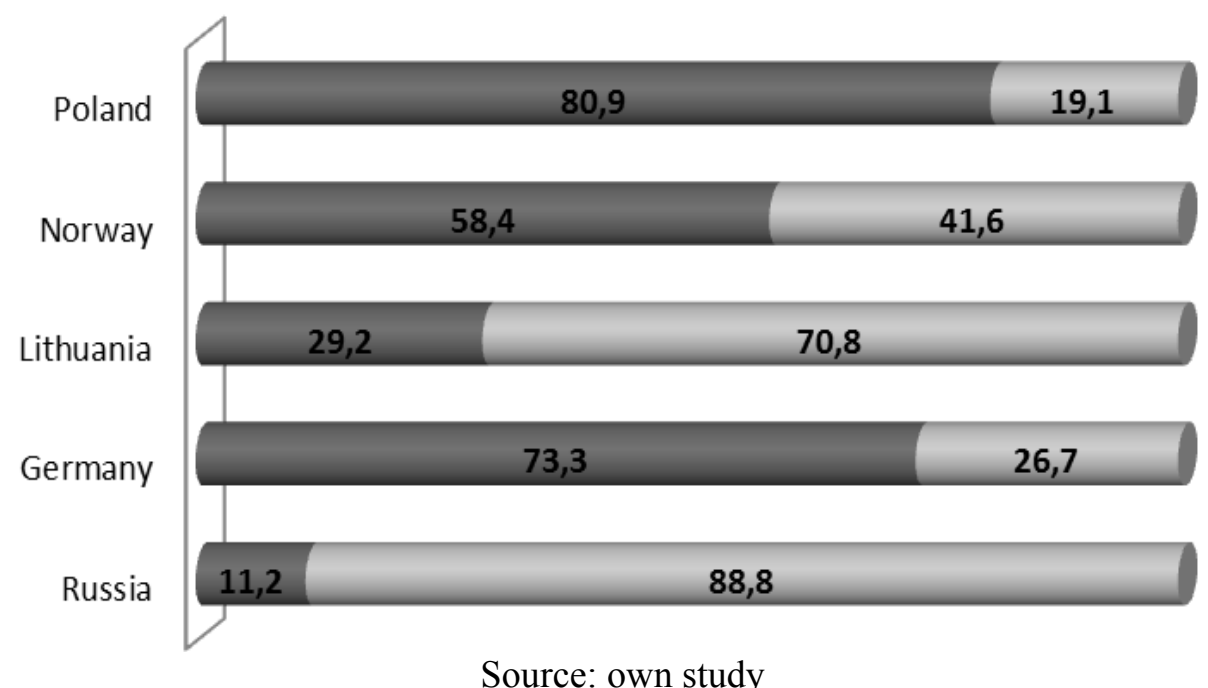

Data: $\mathrm{N}$ for Norway $=25, \mathrm{~N}$ for Lithuania $=24, \mathrm{~N}$ for Germany $=16, \mathrm{~N}$ for Russia $=11$

When inquired about potential activities, that they could undertake in cluster ventures, the SMEs point to different possible activities.

Table 7: Kinds of intended SMEs activities in cluster ventures (in \%)

\begin{tabular}{|l|c|c|c|c|c|}
\hline & Poland & Norway & Lithuania & Germany & Russia \\
\hline \hline joint R\&D & 8,9 & 8 & 41,6 & 6,25 & 36,3 \\
\hline knowledge and technology acquisition & 11,9 & 16 & 20,8 & 12,5 & 9,09 \\
\hline equipment acquisition & 19,9 & 16 & 16,6 & 6,25 & $\mathrm{x}$ \\
\hline joint initiatives in innovations & 13,7 & 24 & 50 & $\mathrm{x}$ & 45,4 \\
\hline $\begin{array}{l}\text { joint market offer/joint marketing } \\
\text { operations }\end{array}$ & 15,2 & 32 & 20,8 & 12,5 & 27,3 \\
\hline $\begin{array}{l}\text { training and consulting services for cluster } \\
\text { members }\end{array}$ & 13,9 & 24 & 33,3 & 12,5 & 36,3 \\
\hline joint market analyses and studies & 14,1 & 20 & 20,8 & 12,5 & 72,7 \\
\hline $\begin{array}{l}\text { initiating cooperation and regional } \\
\text { experience sharing }\end{array}$ & 9,1 & 72 & 33,3 & 37,5 & 18,2 \\
\hline $\begin{array}{l}\text { starting a cooperation and sharing } \\
\text { experience on the international level }\end{array}$ & 7,6 & 4 & 37,5 & 18,75 & 27,3 \\
\hline
\end{tabular}

Source: own study, data: $\mathrm{N}$ for Norway $=25, \mathrm{~N}$ for Lithuania $=24, \mathrm{~N}$ for Germany $=16, \mathrm{~N}$ for Russia $=11$

Very few Polish SMEs have declared an intention to undertake well-defined activities in a cluster. $72 \%$ of the Norwegian and $37,5 \%$ of the German SMEs have been keen to initiate a cooperation and to exchange experience in the region. 50\% of the Lithuanian SMEs have declared readiness to conduct joint innovation ventures, $41,6 \%$ of the SMEs have been interested in R\&D ventures and $37,5 \%$ of the SMEs have shown interest to initiate a cooperation and exchange experience internationally. The Russian SMEs have been willing to participate in joint market analyses $(72,7 \%)$, joint innovative initiatives $(45,4 \%)$, and joint R\&D ventures $(36,3 \%)$. Generally, the more willing SMEs are to participate in a cluster venture (i.e. the Russian, Lithuanian, Norwegian SMEs), the higher intensity of intended ventures in a cluster is. 
Moreover, the study has shown that about $90 \%$ of the analyzed SMEs can see barriers impeding cooperation with scientific institutions. The major barrier SMEs encounter is insufficient proper funds to finance R\&D and difficulties with access to external financing. However, according to the SMEs, the reasons for low intensity of cooperation with R\&D sphere are scientific institutions themselves - SMEs report difficulties with initiating a cooperation with scientific institutions, a lack of interest of these institutions to involve in such a cooperation, and ignorance of the economic subject matter on behalf of these institutions' representatives. An attempt has been made to assess the demand for innovation in SMEs when analyzing the Baltic Sea Region SMEs' innovation potential and their cooperation with $\mathrm{R} \& \mathrm{D}$ sphere.

\section{CONCLUSIONS}

The role, which SMEs play in the economy of the Baltic Sea Region makes creating adequate conditions for their innovation and competitiveness growth a key challenge. For this reason, it is vital to broaden our knowledge of the level of SMEs innovation and to gather data on a demand for innovation support in SMEs - the task that the authors of this report have undertaken.

The sample of the analyzed SMEs consisted of 542 companies from 9 Baltic Region countries and had a large overrepresentation of commercial and service companies as well as mature small and medium-size enterprises (which have been on the market for over 10 years). Because of the fact that the sample of the enterprises used in the study was not representative, the results are not representative either.

In the study, the Baltic Sea region entrepreneurs have been asked to specify a kind and a degree of intensity of innovation changes implemented in their companies. It turns out that marketing and product innovations are most frequent. Moreover, an innovation climate based on openness in organization culture in these companies has proved to be an important factor in innovation implementation in the majority of the analyzed SMEs. SMEs in general have a bad opinion about the innovation climate in the country in which they operate. A difficult access to financing innovation activities by financial institutions is a common problem with building a friendly innovation climate in all the analyzed countries. Major problems, which SMEs struggle with in innovation implementation, are: lack of financial resources, complicated legal procedures, and a deficiency of adequately qualified staff.

While small and medium-sized enterprises face many challenges, effective collaboration with $R \& D$ institutions can provide access to ideas and resources that can be important determinants of firm performance and growth. A cooperation with scientific and R\&D circles and other institutions designed to increase SMEs innovation level is vital on the account of the specificity of SMEs, which generally have limited human resources and a low financial potential. The results of the analysis indicate that local authorities including chambers of crafts and commerce and entrepreneurs associations are major partners in innovation cooperation for SMEs. As far as an SMEs cooperation with R\&D institutions is concerned, a leader-role is generally played by universities. However, according to the SMEs, the reasons for low intensity of cooperation with R\&D sphere are scientific institutions themselves SMEs report difficulties with initiating a cooperation with scientific institutions, a lack of interest of these institutions to involve in such a cooperation, and ignorance of the economic subject matter on behalf of these institutions' representatives. The above results show that it is necessary to start intense activities destined to increase the SMEs' understanding of benefits resulting from a cooperation with scientific institutions. Moreover, abolishment of the barriers identified in this study limiting both innovation implementation processes and SMEs' cooperation with scientific sphere is recommended. 
The author of the study has intended to assess SMEs needs for innovation support from scientific institutions. The demand for specific types of support from universities has been much lower than the analyzed above demand for periodical R\&D. The entrepreneurs have been mostly interested in periodical trainings and workshops for enterprises, which were preparing or which were involved in innovative projects, as well as information meetings on specific types of and kinds of innovations. Such a low level of demand for support from universities is due to the fact that most analyzed SMEs cannot see any potential benefits resulting from a cooperation with scientific institutions. The only positive effect of such a cooperation, which a majority of the analyzed SMEs from all the countries have agreed upon is "launching new products and services". However, the analyzed SMEs have declared a very high demand for trainings and consulting services from scientific environment. Services, products and new technologies are desired fields of a possible cooperation. Unfortunately, a high demand for R\&D is not accompanied by SMEs' intentions to conduct such research in the future. The study shows a high degree of uncertainty among SMEs as to satisfaction of their R\&D needs.

\section{REFERENCES}

1. (2010): The OECD Innovation Strategy: Getting a Head Start on Tomorrow. Paris: OECD Publishing.

2. (2011): Główny Urząd Statystyczny (GUS), www.stat.gov.pl, (downloaded on April 2012).

3. Polska Agencja Rozwoju Przedsiębiorczości (PARP), www.parp.gov.pl, (downloaded on April 2012).

4. Portal Funduszy Europejskich, http://www.ewt.gov.pl, (downloaded on April 2012).

5. Żołnierski A. (2008), Innowacyjność 2008, www.parp.gov.pl, (downloaded on April 2012). 